\title{
Fast implementation of a visual analogue scale (VAS) in an Emergency Department
}

\author{
Hanne Jørsboe*, Bjarne Fogh, Ann Brockdorff \\ From 4th Danish Emergency Medicine Conference \\ Roskilde, Denmark. 25-26 November 2011
}

\section{Background}

Patient satisfaction in an emergency department highly depends on sufficient treatment of pain. Since the VASscale is a useful tool for monitoring pain, the purpose of this study was to investigate if it was possible to implement VAS-scoring in acute patients over a short period of time.

\section{Methods}

A prospective interventional study over 12 weeks. Baseline audits were made weekly 3 times on 25 randomly chosen patient cases. The following interventions were introduced to the triage nurses. All acute patients should be asked about pain using VAS-scale, when arriving to the hospital and the value should be documented together with the vital signs. The nurses were educated in pain treatment and had access to a VAS lineal and a pocket card with treatment algorithm. After the intervention, audits were performed every week on 25 patients through the following 9 weeks. Data will be analyzed with SPC.

Study population was all acutely ill patients older than 15 years, who arrived to the emergency department and had a Glasgow Coma Scale higher than 13.

\section{Results}

Baseline data showed that $22 \%$ of the patients with surgical problems (31\%) were VAS-scored with a mean score higher than 5 . Less than $5 \%$ of the orthopaedic (12\%) and patients with medical diseases (57\%) were VAS-scored. Already after introducing the nurses to use VAS-lineal at triage, a substantial improvement had happened. $85 \%$ of all acute patients were monitored with VAS and followed up, if they had prescribed

* Correspondence: hbjo@regionsjaelland.dk

Akutafdelingen, Nykøbing Falster Sygehus, Denmark painkillers. The following weeks will show if it is possible to maintain the result.

\section{Conclusion}

These preliminary data show, that it is possible to implement the use of VAS-scale for assessment of pain over a short period of time, using a simple strategy in a group of nurses, who already work systematically with triage.

Published: 16 April 2012

doi:10.1186/1757-7241-19-S2-P21

Cite this article as: Jørsboe et al:: Fast implementation of a visual analogue scale (VAS) in an Emergency Department. Scandinavian Journal of Trauma, Resuscitation and Emergency Medicine 2012 19(Suppl 2):P21.

Submit your next manuscript to BioMed Central and take full advantage of:

- Convenient online submission

- Thorough peer review

- No space constraints or color figure charges

- Immediate publication on acceptance

- Inclusion in PubMed, CAS, Scopus and Google Scholar

- Research which is freely available for redistribution 